YESTERDAY IN MEXICO 


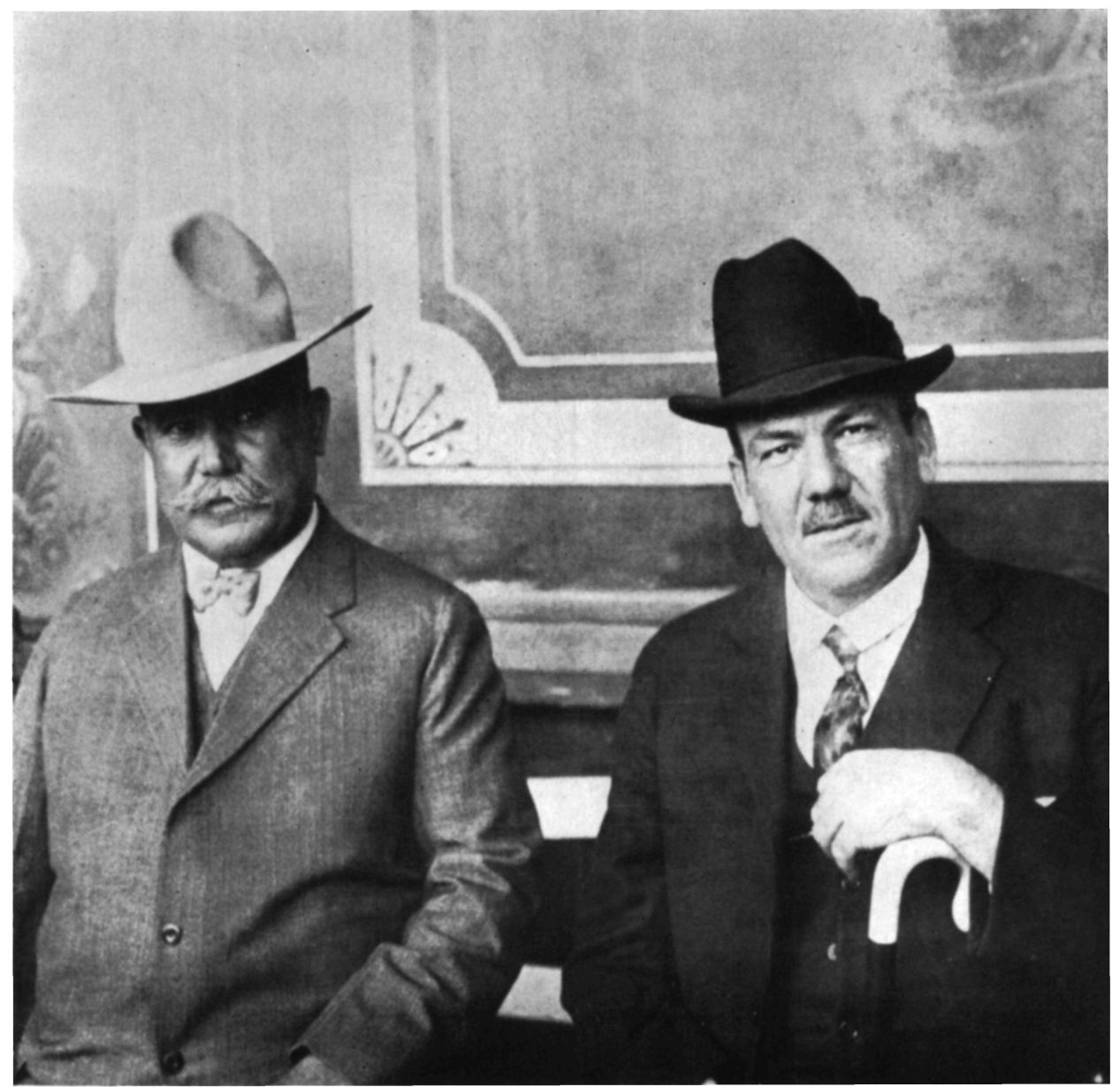

Ex-President Alvaro Obregón and President Elías Calles at Chapultepec Castle 
JOHN W. F. DULLES

\section{YESTERDAY IN MEXICO \\ A Chronicle of the Revolution, 1919-1936}

UNIVERSITY OF TEXAS PRESS, AUSTIN 
Library of Congress Card Catalog No. 60-14309 (C) 1961 by John W. F. Dulles

Manufactured in the United States of America

by the Printing Division of the University of Texas 